\title{
High Efficient Seebeck Thermoelectric Device for Power System Design and Efficiency Calculation: A Review of Potential Household Appliances
}

\author{
T Stephen John \\ Sathyabama University \\ Chennai - 600119
}

\begin{abstract}
The ever growing demand for electricity needs to be fulfilled with due cognizance of the environment factor and recycling energy as effectively as possible. This paper proposes the harnessing of the heat energy wasted in household appliances all of which can generate power in milli watt range. The most promising equipment for the supply of waste heat which can generate power over 1 watt seems to be the gas stove, the experimental feasibility analysis of which is the main target of this paper. Technology used for this end is called TEG which stands for Thermo Electric Generators based on the See beck effect. This device makes use of the temperature gradient across a TEG to generate an electromotive force (emf) across it. TEGs are increasingly in vogue due to lack of mechanical parts, low maintenance and high durability proved in space missions over the past decades. The focus of this paper is rather on the creation of the highest possible temperature difference to produce the highest possible power output.
\end{abstract}

\section{Keywords}

TEG, emf

\section{INTRODUCTION}

Thermoelectricity is the science of conversion of heat energy (temperature difference) into electrical energy (See beck effect) and vice versa (Peltier effect). These are mutually reversible. Thermoelectric power generation is a direct consequence of the Seebeck effect. The See beck effect is the conversion of temperature differences into electricity by a closed loop formed by two different metals joined in two places, with a temperature difference between the junctions; As the metals respond differently to the temperature difference, a current loop and a magnetic field is being created. Waste heat trapped from industry can be utilized in the industry itself. Waste heat from automobile cannot be easily trapped and utilized by us as much as the waste heat from a burning stove is,[1][2] for household purposes.

\subsection{Literature survey for existing system.}

At international level the maximum efficiency for the TEGs is $10 \%[3]$. Though the low efficiency is not a drawback for low power generation $(<\mathrm{W})$ it is the disadvantage for high power generation[4][5]. The use of waste heat $<200$ degree Centigrade substantially increases the method of generating a high electrical power factor (watt per unit area)[6] which is more important than a high value of ' $Z$ '(A high Figure of merit) for waste heat utilization[7][8]. Power factor is enhanced by decreasing the inter element distance between the legs of the thermocouple[9]. The best material for operation in temperatures around 200 degrees celsius is
Bismuth Telluride $\left(\mathrm{Bi}_{2} \mathrm{Te}_{3}\right)$ that is utilized for household gadgets[10][11].

\section{PROPOSED SYSTEM}

Main components of the experimental setup for proposed system are given below.

(1) Water supply (2) pipes (3) Heat sink (4) TEG (5) Tin stand (6) Water container (7) Gas stove (8) Cook ware (9) Multimeter (10) Thermometer

\subsection{Systematic elaboration of the system and its components}

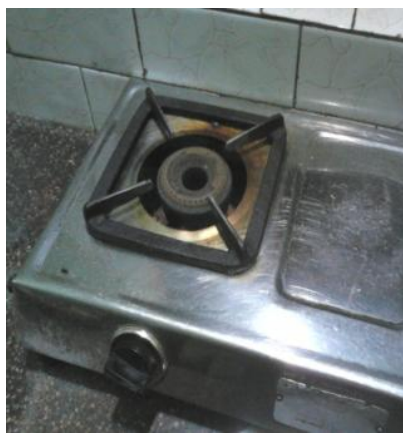

Fig. 1 The existing iron stand in the gas stove

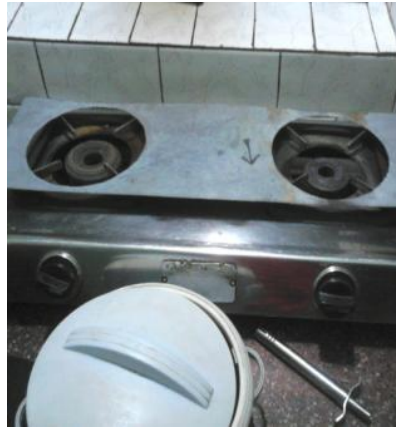

Fig.2 Tin plate placed on the iron stand to trap the flame heat escaping to the surroundings.
When the cookware is placed on the iron stand, the flame heats up the bottom of the cookware to cook the food, but a heat from the flame also escapes around the surroundings. To trap this heat, a Tin stand is made which heats up very fast by trapping some of the heat escaping into the environment, thus making use of the heat which would have been otherwise wasted.

Tin is used because it is the cheapest metal available with a very low specific heat capacity. Specific heat capacity $(C)$ is the amount of heat required to raise the temperature of unit mass of a substance by 1 degree Celsius or Kelvin. The SI unit of $\mathrm{C}$ is $\mathrm{J} / \mathrm{kg}$.K. Low value of $\mathrm{C}$ of a substance means that it can get heated up very fast due to the quick increase in the temperature. This has a direct implication as explained below: 
Table 1. Ascending order of $\mathrm{C}$ of common materials available in the market

\begin{tabular}{|l|l|l|l|l|}
\hline Material & $\begin{array}{l}\mathrm{C} \\
(\mathrm{J} / \mathrm{kg} . \mathrm{K})\end{array}$ & Drawbacks & $\begin{array}{l}\text { Useful } \\
\text { ness }\end{array}$ & $\begin{array}{l}\text { Material } \\
\text { selected }\end{array}$ \\
\hline Gold & 129 & $\begin{array}{l}\text { Very } \\
\text { costly }\end{array}$ & $\begin{array}{l}\text { Very } \\
\text { low }\end{array}$ & \\
\hline Lead & 129 & Poisonous & $\begin{array}{l}\text { Very } \\
\text { low }\end{array}$ & \\
\hline Platinum & 133 & $\begin{array}{l}\text { Very } \\
\text { costly, rare }\end{array}$ & $\begin{array}{l}\text { Very } \\
\text { low }\end{array}$ & \\
\hline Tin & $\mathbf{2 2 8}$ & - & $\begin{array}{l}\text { Very } \\
\text { high }\end{array}$ & Tin \\
\hline Silver & 235 & Costly & Low & \\
\hline Brass & 375 & High C & Low & \\
\hline Copper & 385 & High C & Low & \\
\hline Iron & 449 & High C & Low & \\
\hline Aluminum & 897 & $\begin{array}{l}\text { Very High } \\
\text { C }\end{array}$ & $\begin{array}{l}\text { Very } \\
\text { low }\end{array}$ & \\
\hline & & \multicolumn{2}{|l}{} \\
\hline
\end{tabular}

As per Table 1 Tin was thus selected because of its low cost, easy availability and very low $\mathrm{C}$ which allows its temperature to rise very quickly.

\subsubsection{Temperature measured on the Tin stand}

Table 2. Temperature of the tin stand with (a) 3 litre pressure cooker placed on the tin stand on (b) full flame

\begin{tabular}{|c|c|}
\hline $\begin{array}{c}\text { Position on the tin } \\
\text { stand }\end{array}$ & $\begin{array}{c}\text { Maximum temperature measured in } \\
\text { degree Celsius }\end{array}$ \\
\hline Middle & 140 \\
\hline $\begin{array}{c}\text { Edge/near the } \\
\text { flame }\end{array}$ & 200 \\
\hline
\end{tabular}

- Cookware/utensil used while testing: 3 litre pressure cooker.

- Base diameter of the pressure cooker: $17 \mathrm{~cm}$

- Diameter of the circular hole on the tin plate: $17.2 \mathrm{~cm}$

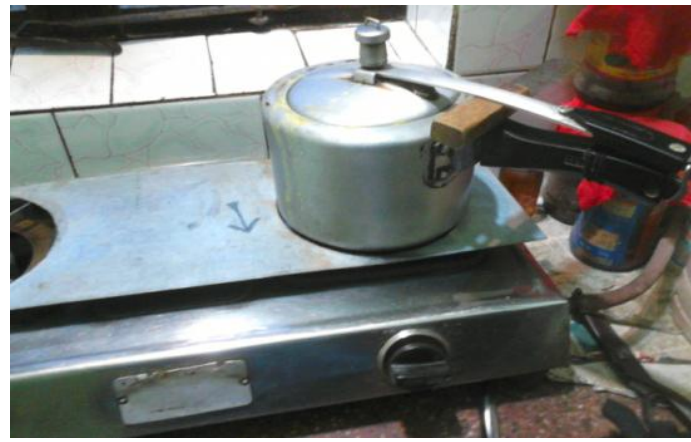

Fig .3 Cooker of base diameter $17 \mathrm{~cm}$

The circular hole is cut out with a radius of $8.6 \mathrm{~cm}$ so that it is more than the cooker radius, so that the cooker does not sit on the tin plate but on the iron stand as it should be near the flame(Table 2). This is necessary because if the cooker sits on the tin plate instead of the iron stand then the distance between the cooker bottom and the flame would increase and lead to more time consumption to cook the food. This is unwanted because if more time is taken to cook food it will mean more supply of gas : which will defeat the very purpose of this paper - to utilize wasted heat energy and to minimize the expenditure of gas for cooking.

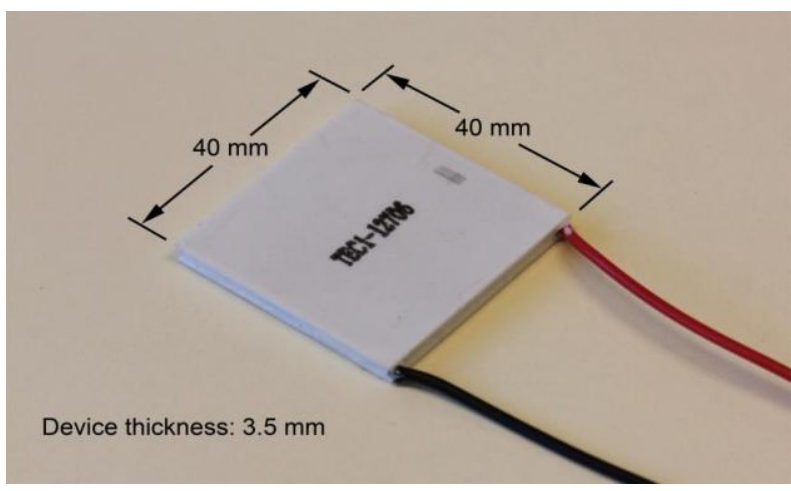

Fig.4 Thermoelectric device for testing (model TEC112706)

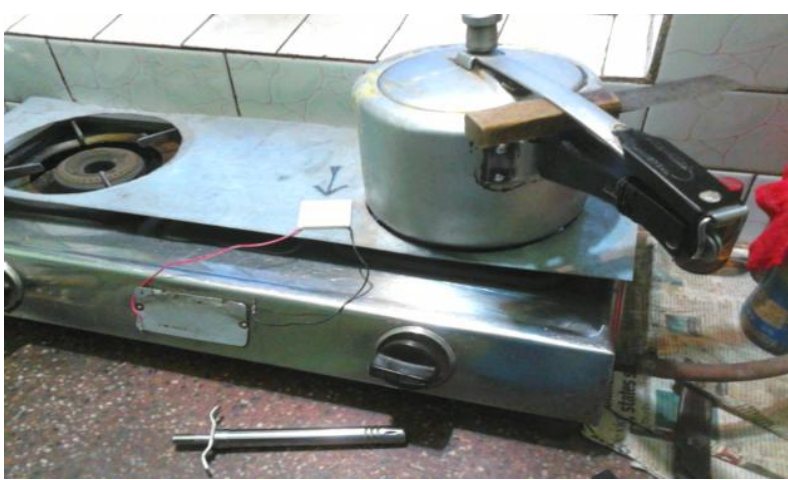

Fig.5 TEG placed near the edge of the tin plate

\subsubsection{TEG used for testing:}

\begin{tabular}{|l|l|}
\hline $\begin{array}{l}\text { Most easily available and } \\
\text { cheapest commercial } \\
\text { TEG } \\
\text { module in India }\end{array}$ & $\begin{array}{l}\text { TEC }-12706 \\
\text { 3 USD (if imported from } \\
\text { China) }\end{array}$ \\
\hline Cost per piece & $\begin{array}{l}385 \text { INR (purchased online } \\
\text { from vododara Gujarat) }\end{array}$ \\
\hline Dimension & $4 \mathrm{~cm} * 4 \mathrm{~cm} * 0.35 \mathrm{~cm}$ \\
\hline $\begin{array}{l}\text { Number of } \\
\text { Thermocouples }\end{array}$ & 127 \\
\hline Thermoelectric Material & Bismuth Telluride $\left(\mathrm{Bi}_{2} \mathrm{Te}_{3}\right)$ \\
\hline Operating temperature & About $200^{\circ}$ Celsius \\
\hline Life expectancy & $2,00,000$ hours \\
\hline
\end{tabular}

The data given here is sourced from the datasheet of the respective TEG models, available online in the manufacturer or supplier website : 
Table 3. Comparison of TEGs available commercially: Modules which can operate under temperature of 200 to $250^{\circ}$

\begin{tabular}{|c|c|c|c|c|c|}
\hline Manufacturer and Country & TEG Model & $\begin{array}{c}\text { Dimensions in } \\
\mathrm{cm} \\
\text { Length*breadth }\end{array}$ & $\begin{array}{l}\mathrm{dT} \text { in } \\
\text { degree } \\
\text { Celsius }\end{array}$ & $\begin{array}{c}\text { Max. } \\
\text { Power } \\
\text { output in } \\
\text { watt }\end{array}$ & $\begin{array}{l}\text { Cost in } \\
\text { USD }\end{array}$ \\
\hline \multirow{6}{*}{ Hi- z Technology Inc., USA } & \multirow{2}{*}{$\mathrm{HZ}-20$} & \multirow{2}{*}{$7.5 * 7.5$} & 200 & 19 & \multirow{2}{*}{125} \\
\hline & & & 100 & 5 & \\
\hline & \multirow{2}{*}{ HZ-14 } & \multirow{2}{*}{$6.27 * 6.27$} & 200 & 14 & \multirow{2}{*}{80} \\
\hline & & & 100 & 2.5 & \\
\hline & \multirow{2}{*}{$\mathrm{HZ}-2$} & \multirow{2}{*}{$2.9 * 2.9$} & 200 & 2.5 & \multirow{2}{*}{34} \\
\hline & & & 10 & 0.5 & \\
\hline \multirow{10}{*}{ Custom Thermoelectric, USA } & \multirow{2}{*}{ 1261G-7L31-04CL } & \multirow{2}{*}{$3 * 3$} & 270 & 5.19 & \multirow{2}{*}{30} \\
\hline & & & 100 & 1.04 & \\
\hline & \multirow{2}{*}{ 1261G-7L31-04CQ } & \multirow{2}{*}{$4 * 4$} & 270 & 5.10 & \multirow{2}{*}{50} \\
\hline & & & 100 & 1.01 & \\
\hline & \multirow{2}{*}{ 1261G-7L31-05CQ } & \multirow{2}{*}{$4 * 4$} & 270 & 7.15 & \multirow{2}{*}{50} \\
\hline & & & 100 & 1.15 & \\
\hline & \multirow{2}{*}{ 1261G-7L31-10CX1 } & \multirow{2}{*}{$5.6 * 5.6$} & 270 & 14.7 & \multirow{2}{*}{79.5} \\
\hline & & & 100 & 3.24 & \\
\hline & \multirow{2}{*}{ 1261G-7L31-24CX1 } & \multirow{2}{*}{$5.6 * 5.6$} & 270 & 19.1 & \multirow{2}{*}{79.5} \\
\hline & & & 100 & 3.54 & \\
\hline \multirow{2}{*}{$\begin{array}{l}\text { Thermal Electronics - } \\
\text { Corp.(TEC),Canada }\end{array}$} & \multirow{2}{*}{ TEG2-07025HT-SS } & \multirow{2}{*}{$4 * 4$} & 180 & 6.8 & \multirow{2}{*}{33} \\
\hline & & & 100 & 2.86 & \\
\hline Laird Technologies, USA & Therma ECSeries HT9,3,F2,2525 & $2.54 * 2.87$ & 150 & 1.125 & 37 \\
\hline \multirow{2}{*}{ China make } & \multirow{2}{*}{ TEC1-12706 } & \multirow{2}{*}{$4 * 4$} & 100 & 2.5 & \multirow{2}{*}{3} \\
\hline & & & 70 & 1.5 & \\
\hline
\end{tabular}

Where, dT - temperature difference between the two sides of TEG

\section{USD - US Dollars.}

\subsubsection{Heat Sink- the most critical component}

Greater the temperature difference between the two sides of the TEG, greater is the power generated. The tin plate heats up to around 200 degree Celsius. This is an almost constant value which cannot be altered at will; so the only way to keep the temperature difference high is to keep the cold side as cool as possible. This task is accomplished by a device called Heat Sink.

Heat sink performance is directly proportional to the following factors:

(a) Thermal conductivity,

(b) Surface area of heat sink available for radiating the heat fins increases the surface area.

The cold side tends to get heated up since that the heat absorbed by the hot side of the TEG is conducted towards the cold side. This heat being conducted to the cold side thus needs to be drawn away in order to keep the cold side really cool. This task is best accomplished by Copper heat sinks as Copper is the best in drawing away heat from bodies as it is a known fact that copper is the best conductor of heat.

As copper heat sinks are rarely available in the market due to its high cost. So the wisely selected metal heat sinks will be Aluminum as it is cheap, light weight and a good conductor of heat too.
Table 4. Materials in descending order of thermal conductivity: higher value means better application as heat sink

\begin{tabular}{|l|c|}
\hline Material & Thermal Conductivity in W/mK \\
\hline Diamond & 1000 \\
\hline Silver & 429 \\
\hline Copper & $\mathbf{4 0 0}$ \\
\hline Gold & 310 \\
\hline Aluminum & $\mathbf{2 3 5}$ \\
\hline Tungsten & 174 \\
\hline Zinc & 116 \\
\hline Brass & 109 \\
\hline Nickel & 91 \\
\hline Iron & 80 \\
\hline Platinum & 70 \\
\hline Cobalt & 69 \\
\hline Tin & 67 \\
\hline
\end{tabular}

The Table 4 shows that diamond followed by silver has the highest thermal conductivity, but high cost renders them unfit for use as heat sinks. Thus the next obvious choice is copper followed by aluminum as gold is exorbitantly expensive. Among copper and aluminum, most of the applications prefer the latter due its lesser cost, lesser weight and easy availability. Nevertheless, a hybrid of copper and aluminum will be the best combination economically.

Heat sinks with copper sheet attached to the Aluminum, will definitely improve the heat drawing ability of the heat sink. The white thermal grease applied to the spot where the TEG is, makes the contact easier. 


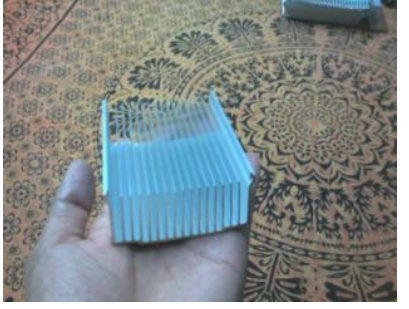

Fig.6 Heat sink 1-

Aluminum $6.2 \mathrm{~cm} * 8.2 \mathrm{~cm}$ 15 fins. The least effective because of small surface area.

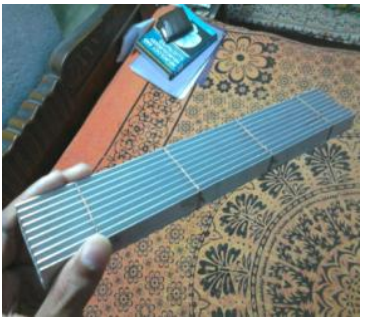

Fig.7 Heat sink 2 Aluminum $5 \mathrm{~cm} * 30 \mathrm{~cm}, 8$ fins. Better than heat sink 1 due to greater surface area.
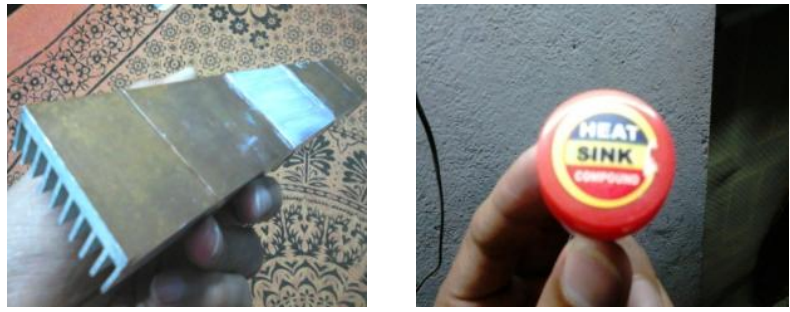

Fig. 8 Heat sink 3 - (Heat sink 2 + copper sheet). White paste like substance applied

Fig.9 Heatsink compound/thermal grease/ thermal paste on it is Thermal Grease.

\subsubsection{Coolant:}

Heat sink draws heat from the cold side of the TEG and gets heated up in turn. It is therefore necessary to cool the heat sink to maintain the cool temperature of the cold side of the TEG. Water is the best coolant naturally available because of its highest Specific heat capacity $4200 \mathrm{~J} / \mathrm{kg}, \mathrm{K}$ of all naturally occurring substances. Water is run through the channels of the heat sink 3. Water from a tap is relayed by a pipe whose end is sealed by plaster of Paris with 9 thin pipes. These thin pipes run into the channels of the heat sink. Thus the water cools the heat sink maintaining a cool temperature.

\section{RESULT AND DISCUSSION \\ Human body}

- Human body(left palm) as heat source at normal body temperature of $36^{\circ} \mathrm{C}$,

- Ambient temperature $32^{\circ} \mathrm{C}$ - March 2014, Padur, Chennai 603103.

- TEG module used: TEC1-12706,

- Heat sink used- no.3 without thermal(water)cooling

\begin{tabular}{|c|c|c|c|}
\hline $\begin{array}{c}\begin{array}{c}\text { Voltage } \\
\text { output } \\
(\mathrm{mV})\end{array} \\
\end{array}$ & $\begin{array}{c}\text { Current } \\
\text { output }(\mathrm{mA})\end{array}$ & $\begin{array}{c}\text { Power= } \\
\mathrm{V}^{*} \mathrm{I}(\mu \mathrm{W})\end{array}$ & Inference \\
\hline 50 & 7.2 & 360 & \multirow{5}{*}{$\begin{array}{l}\text { Body heat } \\
\text { can } \\
\text { generate } \\
\mu \mathrm{W} \text { range } \\
\text { of power. }\end{array}$} \\
\hline 45 & 6.5 & 292.5 & \\
\hline 60 & 8.4 & 504 & \\
\hline 50 & 7.1 & 355 & \\
\hline 60 & 8.6 & 516 & \\
\hline
\end{tabular}

\section{Refrigerator compressor}

- External surface of refrigerator compressor as heat source at $62^{\circ} \mathrm{C}$,

- Ambient temperature $21^{\circ} \mathrm{C}$ - January 2014 , Barrackpore, Kolkata 700120

- $\quad$ TEG module used: TEC1-12706,

- Heat sink used- no.3 without thermal(water)cooling

\begin{tabular}{|c|c|c|c|}
\hline $\begin{array}{c}\text { Output } \\
\text { voltage }(\mathrm{V})\end{array}$ & $\begin{array}{c}\text { Output } \\
\text { current (A) }\end{array}$ & $\begin{array}{l}\text { Power= } \\
\text { V*I (W) }\end{array}$ & Inference \\
\hline 0.70 & 0.43 & 0.30 & \multirow{5}{*}{$\begin{array}{l}\text { Waste heat } \\
\text { from external } \\
\text { surface of } \\
\text { refrigerator } \\
\text { compressor } \\
\text { has the } \\
\text { potential to } \\
\text { generate } \\
\text { around } 0.4 \mathrm{~W}\end{array}$} \\
\hline 0.75 & 0.47 & 0.35 & \\
\hline 0.87 & 0.40 & 0.35 & \\
\hline 1 & 0.38 & 0.38 & \\
\hline 1.25 & 0.28 & 0.35 & \\
\hline
\end{tabular}

\section{Tablet PC}

- $\quad$ Back surface of HCL-ME Tablet PC as heat source at $42^{\circ} \mathrm{C}$

- Ambient temperature- $21^{\circ} \mathrm{C}$, January 2014, Barrackpore, Kolkata 700120

- $\quad$ TEG module used: TEC1-12706

- Heat sink used- no.3 without thermal(water)cooling

\begin{tabular}{|c|c|c|c|}
\hline $\begin{array}{c}\text { Voltage } \\
\text { output } \\
(\mathrm{mV})\end{array}$ & $\begin{array}{c}\text { Current } \\
\text { output } \\
(\mathrm{mA})\end{array}$ & $\begin{array}{c}\text { Power=V } \\
* \mathrm{I}(\mu \mathrm{W})\end{array}$ & Inference \\
\hline 58 & 8.32 & 482.6 & \multirow{5}{*}{$\begin{array}{l}\text { Waste heat at the } \\
\text { back surface of } \\
\text { tablet PCs has the } \\
\text { potential to } \\
\text { generate power in } \\
\mu \mathrm{W} \text { range only }\end{array}$} \\
\hline 59 & 8.32 & 490.9 & \\
\hline 62 & 8.74 & 542.1 & \\
\hline 65 & 8.74 & 568.1 & \\
\hline 62 & 8.73 & 541.3 & \\
\hline
\end{tabular}

Table 5. TEG output power comparison table

\begin{tabular}{|c|c|c|c|}
\hline $\begin{array}{c}\text { Temp } \\
\text { Difference }\end{array}$ & $\begin{array}{c}\text { TEG 1: } \\
\text { TEC1- } \\
\text { 12706 from } \\
\text { India/China }\end{array}$ & $\begin{array}{c}\text { TEG 2: HI-Z } \\
\text { 2,Hi-Z } \\
\text { Technology } \\
\text { Inc. USA }\end{array}$ & $\begin{array}{c}\text { TEG 3: } \\
\text { TEG2- } \\
\text { 07025HT-SS, } \\
\text { from TEC- } \\
\text { TEG, Canada }\end{array}$ \\
\hline $50^{\circ} \mathrm{C}$ & $0.7 \mathrm{~W}$ & $0.2 \mathrm{~W}$ & $0.66 \mathrm{~W}$ \\
\hline $100^{\circ} \mathrm{C}$ & $2.5 \mathrm{~W}$ & $0.5 \mathrm{~W}$ & $2.86 \mathrm{~W}$ \\
\hline
\end{tabular}

According to Table 5 the entire TEGs are suitable for temperature up to 200 degree Celsius. For the paper the researcher is using TEC1-12706 because it is cheap and easily available in India. Each piece costs INR 385 only. 
Table 6 Power output measured for different configuration

\begin{tabular}{|c|c|c|c|c|c|c|}
\hline $\begin{array}{l}\text { Position of TEG on } \\
\text { the tin plate }\end{array}$ & Heat sink & $\begin{array}{c}\text { Thermal cooling- } \\
\text { by water }\end{array}$ & $\begin{array}{c}\text { Voltage } \\
\text { output (V) }\end{array}$ & $\begin{array}{c}\text { Current } \\
\text { output (A) }\end{array}$ & $\begin{array}{c}\text { Power } \\
\text { output }(W)\end{array}$ & Inference \\
\hline Middle of the plate & Heat sink 2 & Yes & $\begin{array}{l}1.25 \\
1.50\end{array}$ & $\begin{array}{l}0.30 \\
0.35\end{array}$ & $\begin{array}{l}0.375 \\
0.525\end{array}$ & $\begin{array}{ll}\text { Middle position not } \\
\text { suitable, less than } 1 \mathrm{~W} \\
\text { generated }\end{array}$ \\
\hline \multirow{4}{*}{$\begin{array}{l}\text { Edge of the plate } \\
\text { (near the flame) }\end{array}$} & Heat sink 1 & No & $\begin{array}{l}1.20 \\
1.20 \\
1.10 \\
1.20 \\
\end{array}$ & $\begin{array}{l}0.12 \\
0.18 \\
0.17 \\
0.17 \\
\end{array}$ & $\begin{array}{l}0.144 \\
0.216 \\
0.187 \\
0.204 \\
\end{array}$ & $\begin{array}{l}\text { Heat sink } 1 \text { not suitable, } \\
\text { less than } 1 \mathrm{~W} \text { generated }\end{array}$ \\
\hline & Heat sink 2 & No & $\begin{array}{l}1.20 \\
1.25\end{array}$ & $\begin{array}{l}0.42 \\
0.48\end{array}$ & $\begin{array}{l}0.504 \\
0.600\end{array}$ & $\begin{array}{l}\text { Thermal cooling } \\
\text { necessary, without it less } \\
\text { than } 1 \mathrm{~W} \text { generated }\end{array}$ \\
\hline & Heat sink 2 & Yes & $\begin{array}{l}2.70 \\
2.50 \\
2.60\end{array}$ & $\begin{array}{l}0.68 \\
0.65 \\
0.67\end{array}$ & $\begin{array}{l}1.836 \\
1.625 \\
1.742\end{array}$ & $\begin{array}{l}\text { Heat sink } 2 \text { with thermal } \\
\text { cooling generates useful } \\
\text { power, more than } 1.5 \text { watt. }\end{array}$ \\
\hline & Heat sink 3 & Yes & $\begin{array}{l}3.26 \\
3.22 \\
3.20\end{array}$ & $\begin{array}{l}0.85 \\
0.84 \\
0.83\end{array}$ & $\begin{array}{l}2.771 \\
2.705 \\
2.656\end{array}$ & $\begin{array}{l}\text { The best configuration, } \\
\text { Heat sink } 3 \text { with thermal } \\
\text { cooling. }\end{array}$ \\
\hline $\begin{array}{l}2 \text { TEGs in series- } \\
\text { Edge of the plate } \\
\text { (near the flame) }\end{array}$ & Heat sink 3 & Yes & $\begin{array}{l}7.00 \\
7.10\end{array}$ & $\begin{array}{l}0.80 \\
0.82\end{array}$ & $\begin{array}{l}5.600 \\
5.822\end{array}$ & $\begin{array}{l}\text { Emf gets added in Series } \\
\text { connection. }\end{array}$ \\
\hline
\end{tabular}

Thus the table makes it absolutely clear that, the best heat sink is heat sink 3, i.e. copper and aluminum hybrid, and the best position for TEG is near the flame at the edge of the tin plate.

Table 7. Temperature \& Efficiency of the semiconductor material pairs

\begin{tabular}{|c|c|c|}
\hline $\begin{array}{c}\text { Semiconductor } \\
\text { Material pair }\end{array}$ & $\begin{array}{c}\text { Efficiency } \\
{[\%]}\end{array}$ & $\begin{array}{c}\text { Temperature } \\
\text { limit }\left[{ }^{\circ} \mathbf{C}\right]\end{array}$ \\
\hline $\mathrm{BiTe}$ & 6 & 300 \\
\hline $\mathrm{PbTe}$ & 9 & 600 \\
\hline $\mathrm{SiGe}$ & 11.5 & 1100 \\
\hline
\end{tabular}

Of the semiconductors cited in Table 7 the BiTe is selected for the study

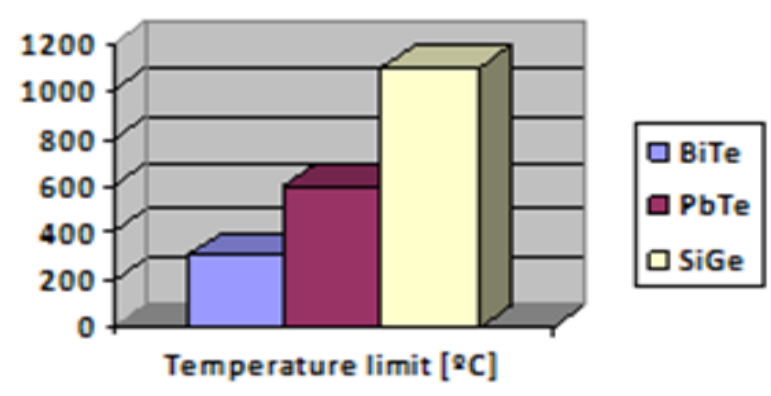

Fig.10 Semiconductor Material pair Vs Temperature

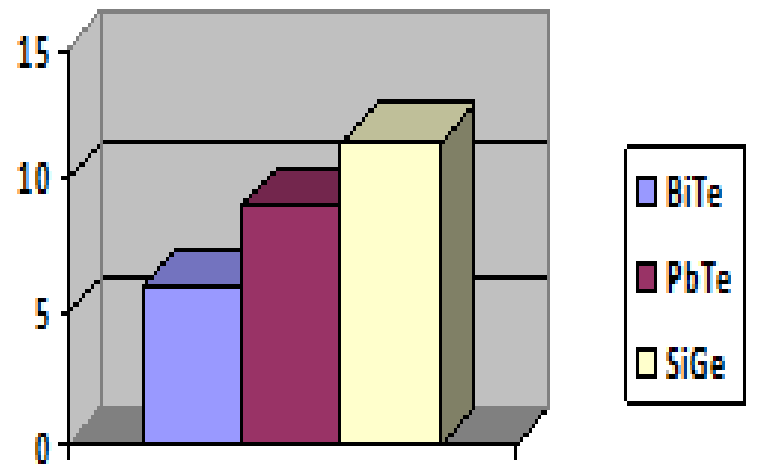

Efficiency [\%]

Fig. 11 Semiconductor Material pair Vs Efficiency [\%]

\subsection{Potential application of the system}

4 TEGs in series will deliver up to 12 volt DC, which is a fairly good amount of voltage. The power delivery can be up to 12 watt which can be used to light a bulb in the kitchen as long as the system is put to use while the cooking takes place. 


\subsection{Economic viability of the system}

Table 8. Cost of the components

\begin{tabular}{|l|l|l|l|}
\hline ITEM & $\begin{array}{l}\text { Cost per } \\
\text { unit in INR }\end{array}$ & $\begin{array}{l}\text { No. of } \\
\text { units }\end{array}$ & Net Cost \\
\hline Pipes & 11 & 10 & 110.00 \\
\hline $\begin{array}{l}\text { Aluminum heat } \\
\text { sink }\end{array}$ & 150 & 1 & 150.00 \\
\hline Copper sheet & 0.125 & 150 & 18.75 \\
\hline Copper wire & 10 & 1 & 10.00 \\
\hline TEC1-12706 & 385 & 4 & 1540.00 \\
\hline Tin plate & 60 & 1 & 60.00 \\
\hline Thermal grease & 10 & 1 & 10.00 \\
\cline { 3 - 4 } & & Total cost & 1898.75 \\
\cline { 2 - 4 } & &
\end{tabular}

- $\quad$ Total Cost of the system $=$ INR 1898.75 or INR 1900 approx.

- Power output = 10 watt or $0.01 \mathrm{KW}$

- Expected lifetime of the system $=200,000$ hour

- Therefore number of units of electrical energy generated in 200,000 hour $=0.01 * 200,000 \mathrm{KWh}=2000$ units, as 1 Unit $=1 \mathrm{KWh}$.

- If the cost per unit is = INR 4,

- $\quad$ Then 2000 units cost = INR 8000 .

Thus, INR 8000 worth of electricity will be generated in the lifetime of the system with a one time expenditure of INR 1900 or 2000 (approx.) incurred to install the system.

\subsection{Cost recovery period:}

Assuming that there is no inflation, the installation cost of INR 2000 will be recovered by 500 units of power generated or 50,000 hour of system operation or 22 year assuming that the system is used for an average of 6 hour per day while cooking in the kitchen is taking place.

\section{CONCLUSION}

The experimental setup of the proposed system successfully generated enough useful thermoelectric power from waste heat, for domestic purposes. Using the cheapest TEG available locally, the thermoelectric power generated was more than 2.5 watt DC per TEG, which is economically attractive. Commercialization of the above system on an industrial scale after further $R \& D$ will significantly reduce the system cost per unit; hence will make the system economically more attractive. Suggestions for future research will be to concentrate on the following aspects or components:

(a) Metal stand $\quad$ : To trap more heat from flame. (b) Heat sink configuration: To increase the temperature difference between the two sides of the TEG and to eliminate the need for thermal cooling using water. (c) TEG

: for better performance.

So the proposed system is indeed economically viable as it can generate power worth at least 4 times the cost of installation, so a lifetime profit of minimum $300 \%$.

\section{REFERENCES}

[1] A. Moser, M. Erd, M. Kostic, K. Cobry, M. Kroener, and P. Woias,"Thermoelectric energy harvesting from transient ambient temperature gradients," J. Electron. Mater., vol. 41, no. 6, pp. 1653-1661, Jun. 2012.

[2] M. E. Kiziroglou, S.W. Wright, T. T. Toh, P. D. Mitcheson, T. Becker, and E. M. Yeatman, "Design and fabrication of heat storage thermoelectric harvesting devices," IEEE Trans. Ind. Electron., vol. 61, no. 1, pp. 302-309, 2014

[3] Hatzikraniotis. E: "On the Recovery of Wasted Heat Using a Commercial Thermoelectric Device", Proceedings of the International Congress on Advances in Applied Physics and Materials Science, Antalya 2011, ACTA PHYSICA POLONICA A, Vol. 121, No. 1, pp. 287-289, 2012.

[4] Hatzikraniotis $\mathrm{E}^{1}$, Zorbas $\mathrm{K}^{1,2}$, Triandafyllis $\mathrm{I}^{2}$ and Paraskevopoulos K.M" : "Study of thermoelectric power generators and application in a small sized car", P2-18-1 to P2-18-4; 1- Physics Department, Solid State Physics Section, Aristotle University of Thessaloniki, 2012.

[5] Julian Goldsmid H: "Introduction to Thermoelectricity", Springer Series in Materials Science 121,Springer 2009.

[6] Riffat S.B, Xiaoli Ma:" Thermoelectrics- a review of present and potential application"s, Applied Thermal Engineering 23 (2003) 913-935, Received 23 August 2002; www.elsevier.com/locate/apthermeng, last accessed on 10 March 2014

[7] Steven O'Halloran, Matthew Rodrigues :'Power And Efficiency Measurement In a Thermoelectric Generator", AC 2012-3976 , American Society for Engineering Education, 2012.

[8] A. Tay, H. T. Chua, Y. Wang, and Y. S. Ngo, "Equipment design and control of advanced thermal processing module in lithography," IEEE Trans. Ind. Electron., vol. 57, no. 3, pp. 1112-1119, Mar. 2010.

[9] J. P. Carmo, L. M. Gonçalves, and J. H. Correia, "Thermoelectric micro converter for energy harvesting systems," IEEE Trans. Ind. Electron.,vol. 57, no. 3, pp. 861-867, Mar. 2010

[10] P. Nenninger and M. Ulrich, "Feasibility of energy harvesting in industrial automation wireless networks," in Proc. 18th IFAC World Congr., 2011,pp. 13 888-13 892.

[11] S. Dalola, M. Ferrari, V. Ferrari, M. Guizzetti, D. Marioli, and A. Taroni, "Characterization of thermoelectric modules for powering autonomous sensors," IEEE Trans. Instrum. Meas., vol. 58, no. 1, pp. 99-107, Jan. 2009. 